\title{
Penerapan Model Pembelajaran Problem Based Learning untuk Meningkatkan Motivasi dan Hasil Belajar Biologi Siswa
}

\author{
Muhammad Wahyu Setiyadi \\ ${ }^{1}$ Program Studi Pendidikan Biologi, STKIP Al Amin Dompu, Indonesia \\ wahyusetiyadi074@gmail.com
}

\begin{abstract}
ARTICLE INFO
Article History:

Received : 12-03-2019

Revised : 18-05-2019

Accepted : 24-05-2019

Online : 30-05-2019

Keywords:

Problem Based Learning;

Motivasi; Hasil Belajar

ABSTRACT

Abstract: this research aims to improve motivation and student learning outcomes in applying Problem Based Learning model. This research is a classroom action research conducted in twi cycle.the subjects of the research was the $X$-Mia $2 M A N 1$ Bima in the academic year of 2018/2019. The research data obtained through observation and test. The result showed an increased by 7,95\%, from 73,73 inthe first cycle and 81,78 in the second cycle. Learning outcomes classiical completeness increaseby $64,29 \%$ of classical completeness $17,86 \%$ in the first cycle and $82,29 \%$ in the second cycle. This result indicate problem based learning model can improve motivation and studen learning outcomes.
\end{abstract}

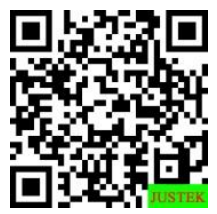

\begin{abstract}
Abstrak: penelitian ini bertujuan ituk meningkatkan motivasi dan hasil belajar biologi siswa dengan menggunakan model pembelajaran Problem Based Learning. Penelitian ini merupakan penelitian tindakan kelas (PTK) yang dilaksanakan dalam dua siklus. Subyek penelitian dalam penelitian ini adalah siswa kelas X-Mia 2 MAN 1 Bima tahun ajaran 2018/2019 data diperoleh melaui observasi dan tes. Hasil penelitian ini terjadi pengkatan motivasi belajar yaitu sebesar 7,95\% dari $73,83 \%$ pada siklus I menjadi $81,78 \%$ pada siklus II. Hasil belajar ketuntasan klasikal meningkat sebesar $64,29 \%$ dimana pada siklus i ketintasan klasikan hanya sebesar $17,86 \%$ sedangkan pada siklus 2 terjadi peningkatan yaitu $82,29 \%$. Hasil ini menunjukkan bahwa model pembelajatan problem based learning dapat meningkatkan motivasi dan hasil belajar biologi siswa.
\end{abstract}


guru masih menggunakan model pembelajaran konvesional dan kebanyakan siswa terlihat kurang memiliki motivasi terhadap matapelajaran biologi. Hal ini berdampak pada hasil belajar siswa, seperti pada rata-rata ujian semester I yaitu 73, dimana nilai tersebut masih berada dibawah kriteria ketuntasan minimal yang telah ditetapkan oleh sekolah tersebut pada matapelajaran biologi yaitu 75. Oleh karena itu dapat dikatakan motivasi dan hasil belajar biologi siswa MAN 1 Bima masih rendah, sehingga dibutuhkan inovasi penggunaan model pembelajaran yang evektif untuk meningkatkan motivasi belajar dan hasil belas siswa khususnya pada mmatapelajaran biologi. Berdasarkan fakta tersebut, perlu upaya guru untuk memperbaiki model pembelajaran agar penguasaan konsep siswa meningkat, sehingga saat pemebelajaran siswa lebih aktif, memahami informasi yang diberikan dan nilai siswa tinggi. Agar siswa aktif dam proses pembelajaran, serta dapat melatih siswa untuk mengekspresiskan idenya sendiri dan membangun pemahaman konsepnya sendiri (Mulia, 2018), serta dalam proses penemuan konsep dan pemecahan masalah (Sari et al., 2018), maka perlu diterapkan suatu model pembelajaran yang sesuai dengan tujuan dan kompetensi yang akan dicapai

Salah satu model pembelajaran yang dapat digunakan adalah model pembelajaran Problem Based Learning merupakann model pembelajaran yang menggunakan masalah dunia nyata atau real world yang terstruktur atau ill-structured dan bersifat terbuka sebagai konteks bagi siswa intuk mengembangkan keterampilan menyelesaikan masalah dan berpikir kritis dan sekaligus membangun pengetahuan baru (Hosnan, 2014). Selanjutnya Abidin (2014) menyatakan Model Problem Based Leraning (PBL) merupakan model pembelajaran yang menyediakan pengalaman otentik yang mendorong siswa untuk belajar aktif, menyusun atau mengonstruksi pengetahuan, dan mengintegrasikan konteks belajar di kehidupan nyata secara alamiah. Sehingga dapat disimpulkan bahwa Problem Based Learning (PBL) adalah model pembelajaran siswa aktif yang mengaitkan informasi baru dengan struktur kognitif yang telah dimiliki siswa sebelumnya (meaningfull learning) melalui kegiatan belajar dalam kelompok untuk mencari solusi dari permasalahan dunia nyata (real world) untuk mengembangkan keterampilan menyelesaikan masalah dengan bantuan berbagai sumber belajar.

Model pembelajaran Problem Based learning dipilih dikarenakan model pembelajaran ini menuntus siswa aktif dalam penyelidikan dan proses pemecahan masakah dalam pembelajaran (Sumitro et al., 2017). Hal ini didukung penelitian dari Fauzan et al., (2017) yang menyatakan model pembelajaran Problem Based Learning dapat meningkatkan Hadil Belasjar Siswa serta hasil penelitian dari Jayadiningrat \& Ati (2018) yang menyatakan dengan memalui model pembelajaran Problem based Learning dapat meningkatakan Keterampilan pemecaham masalah bagi siswa. Berdasarkan permasalahan yang telah dipaparkan di atas maka dapat diketahui bahwa ada beberapa hal yang menyebabkan rendahnya hasil belajar, yaitu (1) rendahnya motivasi siswa dalam mengikuti pembelajaran biologi dan (2) model pembelajaran yang diterapkan guru masih bersifat konvensional dan tidak sesuai dengan pembelajaran biologi. Sebagai alternatif pemecahan masalah maka peneliti memilih menerapkan model Problem Based Learning (PBL) dalam pembelajaran biologi yang diyakini efektif untuk meningkatkan motivasi dan hasil belajar siswa. Penelitian ini bertujuan untuk meningkatkan motivasi dan hasil belajar biologi siswa dengan menggunakan model pembelajaran Problem Based Learning.

\section{B. METODE PENELITIAN}

Jenis Penelitian ini adalah Penelitian tindakan Kelas (PTK). (Supardi \& Suharsini, 2009) mengatakakan penelitian tindakan kelas bertujuan mengetahui akibat tindakan 
yang diteapkan pada suatu subyek penelitian di kelas tersebut. Tahapan-tahapan pelaksanaan meliputi; perencanaan, pelaksanaan, observasi dan refleksi. Pelaksanaan penelitian ini dilakukan di MAN 1 Bima, Kabupaten Bima, semester 1 (satu) tahun ajaran 2018/2019. Subyek penelitian dalam penelitian ini adalah kelas X-Mia 2 dengan jumlah siswa 28 orang. Metode pengumpulan data yang digunakan terdiri atas metode tes dan lebar observasi. Metode tes yang digunakan dalam penelitian ini digunakan untuk mengetahui hasil belajar siswa MAN 1 Bima. Menurut Ahmad (2016) Metode lembar observasi digunakan untuk mengetahui aktivitas kegiatan siswa selama dalam proses pembelajaran. Untuk menganalisis data yang diperoleh dalam penelitian ini digunakan rumus sebagai nerikut:

$$
\begin{gathered}
\% \text { keterlaksanaan pembelajaran }=\frac{\text { jumlah skor }}{\text { skor maksimal }} \times 100 \% \\
\text { Sumber: (Arikunto, 2012) }
\end{gathered}
$$

Hasil persentase keterlaksanaan pembelajaran selanjutnya akan disesuaikan dengan kriteria yang dicapai pada tabel 1 .

Tabel 1. Kriteri keterlaksanaan pembelajaran

\begin{tabular}{cc}
\hline Nilai (\%) & Kriteria keterlaksanaan \\
\hline $81-100$ & Sangat baik \\
$61-80$ & Baik \\
$41-60$ & Cukup baik \\
$21-40$ & Kurang \\
$0-20$ & Sangat kurang \\
\hline
\end{tabular}

$$
\% \text { motivasi belajar }=\frac{\text { jumlah skor }}{\text { skor maksimal }} \times 100 \%
$$

Hasil persentase motivasi belajar selanjutnya disesuaikan dengan kriteria yang dicapai pada tabel 2 .

Tabel 2. Kriteri Motivasi Belajar

\begin{tabular}{cc}
\hline $\mathbf{( \% )}$ & Kriteria Penilaian \\
\hline $81-100$ & Sangat tinggi \\
$61-80$ & Tinggi \\
$41-60$ & Cukup tinggi \\
$21-40$ & Kurang tinggi \\
$0-20$ & Sangat kurang \\
\hline
\end{tabular}

sumber:(Arikunto \& Safrudin, 2014)

$$
\% \text { ketuntasan belajar klasikal }=\frac{\text { jumlah siswa tuntas }}{\text { jumlah semua siswa }} \times 100 \%
$$

Sumber: (Arikunto, 2013)

Kriteria keberhasilan tindakan yang diterapkan dalam penelitian ini meliputi tiga hal yang dapat dilihat pada tabel 3.

Tabel 3. Kriteria Keberhasilan Tindakan

\begin{tabular}{lll}
\hline No & Aspek & Kriteria Keberhasilan Tindakan \\
\hline 1. & Keterlaksanaan pemebelajaran & Keterlaksanaan pemebalajaran mencapai \\
& $\begin{array}{l}\text { menerapkan model pemebelajaran } \\
\text { problem Based Learning }\end{array}$ & Motivasi belajar siswa mencapai persentase \\
2. & Motivasi bealajar siswa & P81\% menunjukan kriteria sangat tinggi \\
& & Persentase ketuntasan klasikal mencapai $\geqslant$ \\
3. & Hasil belajar biologi siswa &
\end{tabular}


80\% dari keseluruhan siswa yang mncapai

KKM matapelajaran Biologi yaitu 75

\section{HASIL DAN PEMBAHASAN}

\section{Hasil}

Pelaksanaan penelitian tindakan siklus 1 dimulai pada tanggal 14 januari 2019 dan petemuan ke tiga dilaksanakan pada tanggal 21 Januari 2019 sedangkan pelaksanaan siklus II dilaksanakan pada tanggal 22 januari 2019 untuk petemuan pertama dan pertemuan ketiga dilaksanakan pada tanggal 29 januari 2019 proses pembelajran berlangsung menggunakan kurikulum 2013 menggunakan model pembelajaran problem based learning pada materi Ekologi semester II. Kegiatan ini teridri dari kegiatan awal, kegiatan inti dan kegiatan akhir. Kegiatan awal dilaksanakan selama 15 menit, kegiatan ini dilaksanakan selama 60 menit dan kegiatan akhir selama 15 menit. Hasil analisi keterlaksanaan pembelajaran, motivasi belajar siswa dan hasil belajar biologi siswa dapat dilihat pada tabel berikut:

Tabel 4. Hasil Analisis Persentase Keterlaksanaan Pembelajaran

\begin{tabular}{ccccc}
\hline & \multicolumn{2}{c}{ Siklus 1 } & Siklus 2 & \\
\cline { 2 - 5 } & $(\%)$ & Kriteria & $(\%)$ & Kriteria \\
\hline Pertemuan 1 & 63,64 & Baik & 81,82 & Sangat baik \\
Pertemuan 2 & 72,73 & Baik & 86,36 & Sangat baik \\
Pertemuan 3 & 81,82 & Sangat baik & 90,91 & Sangat baik \\
\hline Rata-rata & 72,73 & Baik & 86,36 & Sangat baik \\
\hline
\end{tabular}

Berdasarkan hasil analisis persentase keterlaksanaan pembelajaran menggunakan model problem based learning, pada siklus 1 diketahui rata-rata keterlaksanaan pembelajaran sebesar $72,73 \%$ dengan kriteria baik namun belum mencapai kriteria yang telah ditetapkan yaitu dengan rata-rata persentase keterlaksanaan pembelajaran $\geqslant 81 \%$ dengan kriteria sangat baik, akatetapi jika dilihat dari tabel 4 pada saat siklus 1 berlangkung pada pertemuan ke 3 guru sudah mulai memahami langkah langkah yang harus diterapkan dalam pelaksanaan model pembelajaran Problem based learning, hal ini dapat dibuktikan dengan keterlaksanaan pembelajaran yang berhasil dilakukan pada pertemuan ke 3 sebesar $81,82 \%$ yang masuk dalam kriteria keterlaksanaan pembelajaran sangat bauk. sedangkan pada siklus II dapat diketahui rata-rata persentase keterlaksanaan pembelajaran problem based learning adalah sebesar 86,36\% yang berarti telah memenuhi kriterian persentase rata-rata $\geqslant 81 \%$ dengan kriteria sangat baik.

Tabel 5. Hasil Analisis Persentase Motivasi Belajar Siswa

\begin{tabular}{ccccc}
\hline Motivasi Belajar & \multicolumn{2}{c}{ Siklus 1 } & Siklus 2 & \\
\cline { 2 - 5 } ARCS & $(\%)$ & Kategori & $(\%)$ & Kategori \\
\hline Attention & 74,18 & Tinggi & 83,41 & Sangat tinggi \\
Relevance & 74,38 & Tinggi & 81,43 & Sangat tinggi \\
Confidence & 73,47 & Tinggi & 81,02 & Sangat tinggi \\
satisfaction & 73,30 & Tinggi & 81,25 & Sangat tinggi \\
\hline Rata-rata(\%) & 73,83 & Tinggi & 81,78 & Sangat tinggi \\
\hline
\end{tabular}

Berdasarkan hasil analisis persentase motivasi belajar siswa menggunakan model problem based learning, pada siklus 1 diketahui rata-rata motivasi belajar siswa sebesar 73,83\% dengan kriteria tinggi namun belum mencapai kriteria yang telah ditetapkan yaitu dengan rata-rata persentase motibasi belajar siswa $\geqslant 81 \%$ dengan kriteria sangat baik sedangkan pada siklus II dapat diketahui rata-rata persentase motivasi belajar siswa menggunakan model problem based learning 
mengalami peningkatan yaitu sebesar $86,36 \%$ yang berarti telah memenuhi kriterian persentase rata-rata $\geqslant 81 \%$ dengan kriteria sangat baik

Tabel 6. Hasil Analisis Hasil Belajar Biologi Siswa

\begin{tabular}{ccccc}
\hline Hasil Belajar & \multicolumn{2}{c}{ Siklus 1 } & Siklus 2 & \\
\cline { 2 - 5 } & Rata-rata & $\begin{array}{c}\text { Ketuntasan } \\
\text { Klasikal (\%) }\end{array}$ & Rata-rata & $\begin{array}{c}\text { Ketuntasan } \\
\text { Klasikal (\%) }\end{array}$ \\
\hline kognitif & 61,75 & 17,86 & 83,11 & 82,14 \\
\hline
\end{tabular}

Berdasarkan hasil analisis hasil belajar biologi pada materi ekologi siswa menggunakan model problem based learning, pada siklus 1 diketahui rata-rata hasil belajar siswa sebesar 61,75\% dengan dengan ketuntasan klasiskal sebesar 17,86\%, hal ini menunjukan bahawa hasil belajar biologi pada siklus 1 masih belum mencapai kriteria yang telah ditetapkan yaitu pembelajaran dikatakan tuntas jika ketuntasan klasikal pembelajaran tersebut $\geqslant 80 \%$. Sedangkan pada siklus II dapat diketahui rata-rata hasil belajar siswa menggunakan model problem based learning mengalami peningkatan yaitu sebesar $83,11 \%$ dengan ketuntasan klasikal sebesar $82,14 \%$ yang berarti telah memenuhi kriteria ketuntasan klasikal $\geqslant 80 \%$.

\section{Pembahasan}

Berdasarkan observasi siklus I pelaksanaan pemebelajaran menggunakan model pembelajaran Problem Based Learning ditemukan beberapa kendala seperti guru sering melupakan untuk melakukan kegiatan apersepsi yang dimana tujuan dari dilakukannya kegiatan apersepsi adalah untuk menggali kemampuan atau pengetahuan awal dari siswa sebelum dimulaianya kegiatan inti pembelajaran, hal ini didukung oleh pendapat Ningsih et al.,(2013)yang meyatakan bahwa kegiatan memberikan apersepsi adalah kegiatan yang dilakukan oleh guru untuk menciptakan suasana siap mental dan menimbulkan perhatian siswa agar terpusat pada hal-hal yang akan dipelajari. Selain itu pada siklus I guru juga sering melupakan tahapan refleksi. Selain itu berdasarkan hasil keterampilan guru dalam mengelola pembelajaran terdapat beberapa keterampilan guru yang masih kurang diantaranya adalah ketika memberi informasi mengetai materi yang akan dipelajari, ketika membagikan siswa kedalam kelompok, mendemonstrasikan materi, ketika memberikan kesempatan pada siswa untuk berpikir, memcahkan masalah dan berdiskusi, ketika membimbing siswa dalam berdiskusi, ketika memberikan penguatan materi dan membimbing siswa membuat kesimpulan, kurangnya keterampilan guru dlam mengajak siswa aktif dan antusias dalam pembelajaran serta ketika mengkondisikan pemebelajaran berpusat pada siswa.

Pada siklus dua guru sudah dapat memehami langkal-langkah dardri model pembelajaran PBL hal ini dapat dilihat dari keterlaksanaan pembelajaran yang meningkat sebesar 13,64\% dimana pada siklus i keterlaksanaan pembelajaran sebesar 72,73\% menjadi $86,36 \%$ pada siklus II. Selain itu guru juga sudah dapat membimbing siswa dalam melaksanakan pembelajaran menggunakan model pembelajaran problem based learning atau PBL. Hal ini dapat dilahat dari peningkatan motivasi dan hasil belajar biologi siswa. Peningkatan motivasi siswa sebesar $7,95 \%$ dari $73,83 \%$ pada siklus I menjadi 81,78\% pada siklus II. Pengukuran motivasi siswa dilihat dadi empat aspek yaitu Attention, Relevance, Confidence dan Satisfaction. Pada siklus I motivasi siswa pada kempat aspek ini telah termasuk dalam kategori tinggi walaupun masih belum sesuai dengan kriteria penetapan motivasi $\geqslant 81 \%$. Sedangkan pada siklus II motivasi siswa pada keempat aspek tersebut mengalami kenaikan yang cukup signifikan dimana ke empat aspek trsebut masuk dalam kategori sangat tingggi. Hal ini membuktikan bahawa penerapan model pembelajaran problem bbasel learning dapat 
meningkatkan motivasi siswa. Sejalan dengan penelitian dari Sumitro et al.,(2017) yang dalam penelitiannnya model pembelajaran dapat meningkatakan motvasi dan hasil belajar siswa.

Pembelajaran dikatakan berhasil secara klasikal jika minimal 80\% siswa mencapai nilai minimal 75 (Setiyadi, 2017b). Berdasarkan hasil penelitian didapatkan hasil bahwan hasi belajar siswa mengalami peningkayan secara klasikal sebesar $64,29 \%$ dimana pada siklus i ketintasan klasikan hanya sebesar $17,86 \%$ dengan ratarata 61,75 sedangkan pada siklus 2 terjadi peningkatan yaitu $82,29 \%$ dengan ratarata nilai 83,11 . Hasil ini menunjukkan bahwa model pembelajatan problem based learning dapat meningkatkan motivasi dan hasil belajar biologi siswa. Hal ini didukung oleh penellitian Bungel,( 2014) dan Paloloang, (2014) yang meyatakan bahwa penerapan model pembelajaran problem based learning dapat meningkatkan hasil belajar siswa.

Abidin (2014) menyatakan Model Problem Based Leraning (PBL) merupakan model pembelajaran yang menyediakan pengalaman otentik yang mendorong siswa untuk belajar aktif, menyusun atau mengonstruksi pengetahuan, dan mengintegrasikan konteks belajar di kehidupan nyata secara alamiah. Sehingga dapat disimpulkan bahwa Problem Based Learning (PBL) adalah model pembelajaran siswa aktif yang mengaitkan informasi baru dengan struktur kognitif yang telah dimiliki siswa sebelumnya (meaningfull learning) melalui kegiatan belajar dalam kelompok untuk mencari solusi dari permasalahan dunia nyata (real world) untuk mengembangkan keterampilan menyelesaikan masalah dengan bantuan berbagai sumber belajar. Dengan demikian siswa diharapkan akan dapat meningkatakan keterlibatannya dalam kegiatan pembelajaran. Peningkatan keterlibatan siswa kegiatan pembelajaran diasumsikan dapat meningkatakan hasil pemebelajaran (Setiyadi, 2017a). Model pembelajaran Problem Based learning dipilih dikarenakan model pembelajaran ini menuntus siswa aktif dalam penyelidikan dan proses pemecahan masakah dalam pembelajaran (Sumitro et al., 2017). Melalui problem based learning, siswa dituntut untuk mengembangkan kemampuan berfikit tingkat tinggi, pemecahan maslah dan keterampilan intelektual (Jayadiningrat \& Ati, 2018). Mereka juga diharapkan mampu belajar berbagai peran orang dewasa melalui pelibatan mereka dalam pengalaman nyata. Pada akhirnya pembelajaran berbasis masalah akan melatih siswa menjadi pebelajar yang mandiri.

\section{SIMPULAN DAN SARAN}

Adapun kesimpulan dalam penelitian ini adalah sebagai berikut: (1) keterlaksanaan pemebelajaran menggunakan model pembelajaran Problem based learning mengalami peningkatas sebesar $13,64 \%$ dimana pada siklus i keterlaksanaan pembelajaran sebesar $72,73 \%$ menjadi $86,36 \%$ pada siklus II; (2) motivasi pembelajaran mengalami peningkatan terjadi pengkatan motivasi belajar yaitu sebesar 7,95\% dari 73,83\% pada siklus I menjadi 81,78\% pada siklus II; (3) hasil belajar ketuntasan klasikal meningkat sebesar 64,29\% dimana pada siklus i ketintasan klasikan hanya sebesar 17,86\% sedangkan pada siklus 2 terjadi peningkatan yaitu 82,29\%. Hasil ini menunjukkan bahwa model pembelajatan problem based learning dapat meningkatkan motivasi dan hasil belajar biologi siswa.

\section{REFERENSI}

Abidin, Y. (2014). Desain Sistem Pembelajaran dalam Konteks Kurikulum. Revika Aditama. Ahmad, F. (2016). Penerapan Model Pembelajaran Kooperatif Tipe Pair Checks Dalam Meningkatkan Motivasi dan Hasil Belajar IPA Tepadu Siswa Kelas VIIIA SMP Negeri 
1 Tabulahan Kab. Mamasa. Sainsmat, 5(2), 137-142. http://ojs.unm.ac.id/index.php/sainsmat/article/view/3241/1859

Arikunto, S. (2012). Prosedur Penelitian: Suatu Pendekatan Praktik. Rineka Cipta.

Arikunto, S. (2013). Penelitian Tindakan Kelas. Bumi Aksara.

Arikunto, S., \& Safrudin. (2014). Evaluasi Program Pendidikan. Bumi Aksara.

Bungel, M. F. (2014). Penerapan Model Pembelajaran Problem Based Learning Untuk Meningkatkan Hasil Belajar Siswa Kelas Viii Smp Negeri 4 Palu Pada Materi Prisma. Pendidikan Matematika Tadulako, 2(1), 45-54.

Fauzan, M., Gani, A., \& Syukri, M. (2017). Penerapan Model Problem Based Learning Pada Pembelajaran Materi Sistem Tata Surya Untuk Meningkatkan Hasil Belajar Siswa. Jurnal Pendidikan Sains Indonesia (Indonesian Journal of Science Education), 5(1), 27-35. http://www.jurnal.unsyiah.ac.id/JPSI/article/view/8404/6797

Hosnan, M. (2014). Pendekatan Saintifik dan Kontekstual dalam Pembelajaran Abad 21. Ghalia Indonesia.

Jayadiningrat, M. G., \& Ati, E. K. (2018). Peningkatan Keterampilan Memecahkan Masalah Melalui Model Pembelajaran Problem Based Learning (Pbl) Pada Mata Pelajaran Kimia. Jurnal Pendidikan Kimia Indonesia, 2(1), 1. https://doi.org/10.23887/jpk.v2i1.14133

Mulia, S. D. B. (2018). Efektivitas Problem Based Learning Terhadap Kemampuan Komunikasi Matematis Siswa Septi. Pendidikan Matematika Universitas Lampung, 6(6), 459-470. http://jurnal.fkip.unila.ac.id/index.php/MTK/article/view/15939

Ningsih, N., Mastuti, S. E., \& Aminuyati, A. (2013). Perbedaan Pengaruh Pemberian Apersepsi Terhadap Kesiapan Belajar Siswa Mata Pelajaran IPS Kelas VII A. Jurnal Pendidikan Dan Pembelajaran Khatulistiwa, 2(6). https://www.neliti.com/publications/216152/perbedaan-pengaruh-pemberianapersepsi-terhadap-kesiapan-belajar-siswa-mata-pela

Paloloang, M. F. B. (2014). Penerapan Model Problem Based Learning (PBL) untuk Meningkatkan Hasil Belajar Siswa pada Materi Panjang Garis Singgung Persekutuan Dua Lingkaran di Kelas VIII SMP Negeri 19 Palu. Jurnal Elektronik Pendidikan Matematika Tadulako, 2(1), 67-77.

Riduwan. (2013). Skala Pengukuran Variabel-Variabel Penelitian (10th ed.). Alfabeta.

Sari, A. P., Rudibyani, R. B., \& Efkar, T. (2018). Efektivitas Problem Based Learning untuk Meningkatkan Keterampilan Berpikir Luwes Siswa pada Materi Asam Basa. Jurnal Pendidikan Dan Pembelajaran Kimia (JPPK), 7(2), 1-16. https://core.ac.uk/download/pdf/294901205.pdf

Setiyadi, M. W. (2017a). Perbedaan Hasil Belajar IPA Terpadu antara Pemberian Tugas di Awal Pembelajaran Dengan Pemberian Tugas di Akhir Pembelajaran pada Siswa Kelas VII SMP Negeri 1 Bolo Tahun Ajaran 2016-2017. VI(1), 1-11. http://ejournal.kopertais4.or.id/sasambo/index.php/alfurqan/article/view/3229

Setiyadi, M. W. (2017b). Pengembangan Modul Pembelajaran Biologi Berbasis Pendekatan Saintifik Untuk Meningkatkan Hasil Belajar Siswa. Journal of Educational Science and Technology (EST), 3(2), 102. https://doi.org/10.26858/est.v3i2.3468

Sumitro, A. H., Setyosari, P., \& Sumarmi. (2017). Penerapan Model Problem Based Learning meningkatkan Motivasi dan Hasil Belajar IPS. Jurnal Pendidikan:Teori, Penelitian, Dan Pengembangan, 2(9), 1188-1195. http://journal.um.ac.id/index.php/jptpp/article/view/9936/4696

Supardi, S., \& Suharsini, A. (2009). Penelitian Tindakan Kelas. Bumi Aksara. 